NASA/TM-2010-216232

\title{
Test Rack Development for Extended Operation of Advanced Stirling Convertors at NASA Glenn Research Center
}

Gina M. Dugala

Glenn Research Center, Cleveland, Ohio 


\section{NASA STI Program . . . in Profile}

Since its founding, NASA has been dedicated to the advancement of aeronautics and space science. The NASA Scientific and Technical Information (STI) program plays a key part in helping NASA maintain this important role.

The NASA STI Program operates under the auspices of the Agency Chief Information Officer. It collects, organizes, provides for archiving, and disseminates NASA's STI. The NASA STI program provides access to the NASA Aeronautics and Space Database and its public interface, the NASA Technical Reports Server, thus providing one of the largest collections of aeronautical and space science STI in the world. Results are published in both non-NASA channels and by NASA in the NASA STI Report Series, which includes the following report types:

- TECHNICAL PUBLICATION. Reports of completed research or a major significant phase of research that present the results of NASA programs and include extensive data or theoretical analysis. Includes compilations of significant scientific and technical data and information deemed to be of continuing reference value. NASA counterpart of peer-reviewed formal professional papers but has less stringent limitations on manuscript length and extent of graphic presentations.

- TECHNICAL MEMORANDUM. Scientific and technical findings that are preliminary or of specialized interest, e.g., quick release reports, working papers, and bibliographies that contain minimal annotation. Does not contain extensive analysis.

- CONTRACTOR REPORT. Scientific and technical findings by NASA-sponsored contractors and grantees.
- CONFERENCE PUBLICATION. Collected papers from scientific and technical conferences, symposia, seminars, or other meetings sponsored or cosponsored by NASA.

- SPECIAL PUBLICATION. Scientific, technical, or historical information from NASA programs, projects, and missions, often concerned with subjects having substantial public interest.

- TECHNICAL TRANSLATION. Englishlanguage translations of foreign scientific and technical material pertinent to NASA's mission.

Specialized services also include creating custom thesauri, building customized databases, organizing and publishing research results.

For more information about the NASA STI program, see the following:

- Access the NASA STI program home page at http://www.sti.nasa.gov

- E-mail your question via the Internet to help@ sti.nasa.gov

- Fax your question to the NASA STI Help Desk at $443-757-5803$

- Telephone the NASA STI Help Desk at 443-757-5802

- Write to: NASA Center for AeroSpace Information (CASI) 7115 Standard Drive Hanover, MD 21076-1320 
NASA/TM-2010-216232

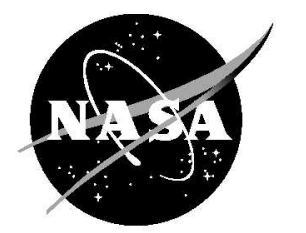

\section{Test Rack Development for Extended Operation of Advanced Stirling Convertors at NASA Glenn Research Center}

Gina M. Dugala

Glenn Research Center, Cleveland, Ohio

Prepared for the

Seventh International Energy Conversion Engineering Conference (IECEC)

sponsored by the American Institute of Aeronautics and Astronautics

Denver, Colorado, August 2-5, 2009

National Aeronautics and

Space Administration

Glenn Research Center

Cleveland, Ohio 44135 


\section{Acknowledgments}

The work described in this paper was performed for the Science Mission Directorate and the Radioisotope Power System Program, which funded these projects.

Trade names and trademarks are used in this report for identification only. Their usage does not constitute an official endorsement, either expressed or implied, by the National Aeronautics and Space Administration.

Level of Review: This material has been technically reviewed by technical management.

Available from

NASA Center for Aerospace Information 7115 Standard Drive

Hanover, MD 21076-1320
National Technical Information Service 5301 Shawnee Road Alexandria, VA 22312

Available electronically at http://gltrs.grc.nasa.gov 


\title{
Test Rack Development for Extended Operation of Advanced Stirling Convertors at NASA Glenn Research Center
}

\author{
Gina M. Dugala \\ National Aeronautics and Space Administration \\ Glenn Research Center \\ Cleveland, Ohio 44135
}

\begin{abstract}
The U.S. Department of Energy, Lockheed Martin Space Systems Company, Sunpower Inc., and NASA Glenn Research Center (GRC) have been developing an Advanced Stirling Radioisotope Generator (ASRG) for use as a power system on space science missions. This generator will make use of free-piston Stirling convertors to achieve higher conversion efficiency than with currently available alternatives. One part of NASA GRC's support of ASRG development includes extended operation testing of Advanced Stirling Convertors (ASCs) developed by Sunpower Inc. and GRC. The ASC consists of a free-piston Stirling engine integrated with a linear alternator. NASA GRC has been building test facilities to support extended operation of the ASCs for several years. Operation of the convertors in the test facility provides convertor performance data over an extended period of time. One part of the test facility is the test rack, which provides a means for data collection, convertor control, and safe operation. Over the years, the test rack requirements have changed. The initial ASC test rack utilized an alternatingcurrent (AC) bus for convertor control; the ASRG Engineering Unit (EU) test rack can operate with AC bus control or with an ASC Control Unit (ACU). A new test rack is being developed to support extended operation of the ASC-E2s with higher standards of documentation, component selection, and assembly practices. This paper discusses the differences among the ASC, ASRG EU, and ASC-E2 test racks.
\end{abstract}

\section{Introduction}

Extended operation of Advanced Stirling Convertors (ASCs) has been an ongoing effort at the NASA Glenn Research Center (GRC) since 2006. This effort was initiated to demonstrate the life and reliability of Stirling convertors. Extended operation involves continuous, unattended convertor operation over a period of thousands of hours. The test rack provides the means for measuring and collecting data for observing operating trends. In addition, it provides convertor control and safe operation. Figure 1 shows test racks in GRC's Stirling Research Laboratory.

Sections II, III, and IV of this paper describe the three test rack designs used at GRC. The first test rack was designed for operating ASCs with AC bus control. Figure 2 shows a pair of ASC test articles on a test stand. The second test rack was designed for operating an Advanced Stirling Radioisotope Generator Engineering Unit (ASRG EU) with AC bus control or with an ASC Control Unit (ACU). Figure 3 shows a cutaway drawing of the ASRG EU. The third test rack was designed for operating ASC-E2 convertors with the intent of improving the quality of the test rack. The ASC-E2 is a second generation of the engineering-level Stirling convertor development. This test article will resemble the one shown in Figure 2. Each test rack allows the adjustment of operating conditions, including hot-end temperature, rejection temperature, and piston amplitude. Each test article was instrumented to measure these parameters in addition to output characteristics such as alternator voltage, current, power, and operating frequency. The test racks differ primarily in the instrumentation used to accomplish these measurements, to implement safe operation, and to control the convertor. 


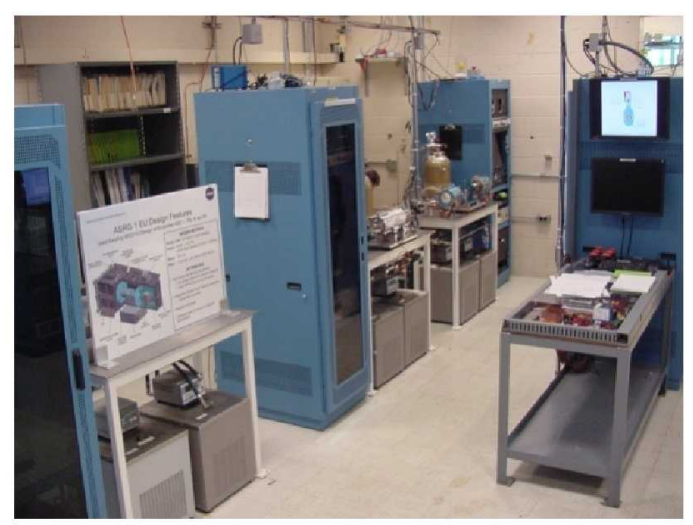

Figure 1.-Test racks in the Stirling Research Laboratory.

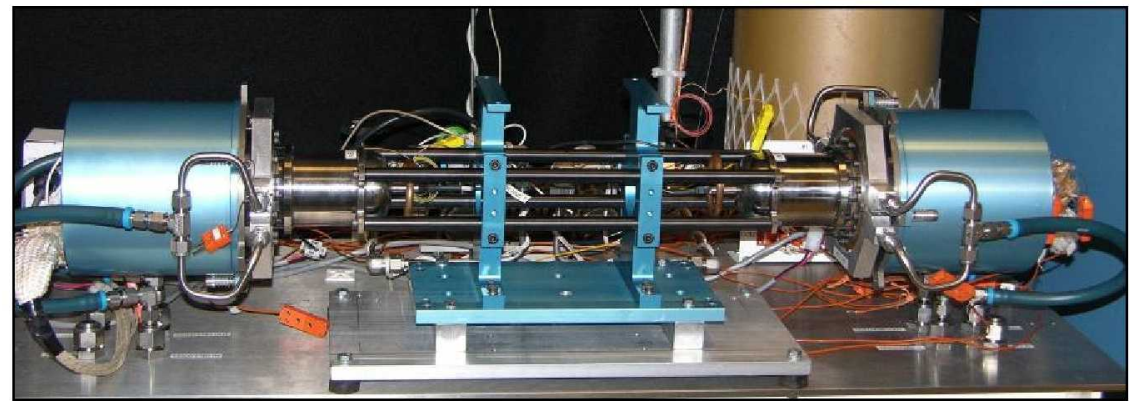

Figure 2.-Standard ASC test article (Ref. 2).

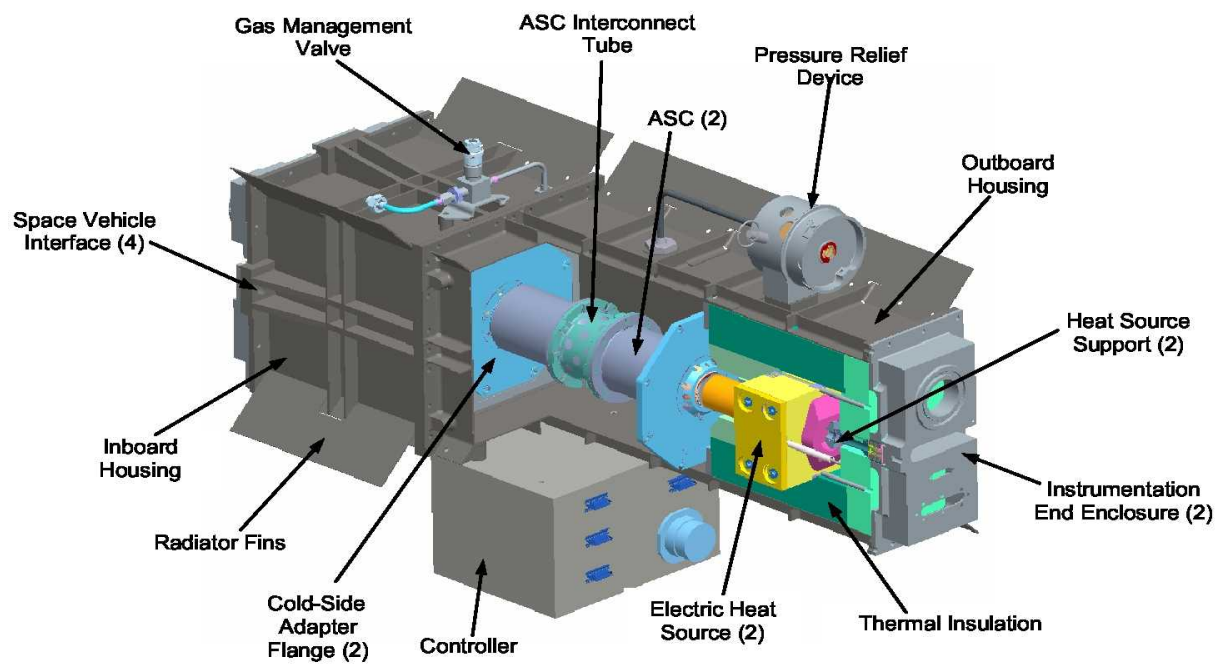

Figure 3.-ASRG-EU test article (Ref. 2). 
All test articles described in this paper consist of a pair of convertors mounted in the dual-opposed configuration, with the heater heads facing outward and the pressure vessel sections rigidly attached to each other. This configuration permits operation that is dynamically balanced because the piston motions are equal but opposite in direction. The hot end of each convertor is heated with electric cartridge heaters. The cold end of the standard ASCs and the ASC-E2s is maintained with a water/glycol bath, and that of the ASRG EU is air-cooled. Table 1 shows the approximate hot-end and cold-end temperatures of the convertors as well as the approximate alternator voltage and current of each of the convertors.

TABLE 1.-ASC, ASRG-EU, AND ASC-E2 TEST ARTICLE OPERATING CONDITIONS (REF. 1).

\begin{tabular}{|c|c|c|c|c|}
\hline \multirow[t]{2}{*}{ Convertors } & \multicolumn{2}{|c|}{$\begin{array}{c}\text { Nominal operating } \\
\text { temperature }\end{array}$} & \multirow{2}{*}{$\begin{array}{c}\text { Alternator } \\
\text { voltage, } \\
V_{\text {rms }}\end{array}$} & \multirow{2}{*}{$\begin{array}{c}\text { Alternator } \\
\text { current, } \\
\text { A }\end{array}$} \\
\hline & $\begin{array}{l}T_{\text {hot }}, \\
{ }^{\circ} \mathrm{C}\end{array}$ & $\begin{array}{l}T_{\text {cold, }} \\
{ }^{\circ} \mathrm{C}\end{array}$ & & \\
\hline \multicolumn{5}{|c|}{ Standard ASC } \\
\hline $\mathrm{ASC}-0 \# 1$ and $\# 2$ & 645 & 72 & 24 & 3.5 \\
\hline ASC $-0 \# 3$ and \#4 & 650 & 90 & 24 & 3.5 \\
\hline ASC- 1 \#3 and \#4 & 850 & 90 & 10.9 & 8 \\
\hline ASC-1HS \#1 and \#2 & 850 & 90 & 24 & 3.5 \\
\hline ASC-E \#1 and \#4 & 650 & 90 & 10.9 & 8 \\
\hline \multicolumn{5}{|c|}{ ASRG-EU } \\
\hline ASC-E \#2 and \#3 & 640 & 90 & 10.9 & 8 \\
\hline \multicolumn{5}{|c|}{ ASC-E2 } \\
\hline ASC-E2 \#1 and \#2 & 850 & 90 & 10.9 & 8 \\
\hline $\mathrm{ASC}-\mathrm{E} 2 \# 3$ and \#4 & 850 & 90 & 10.9 & 8 \\
\hline ASC-E2 \#5 and \#6 & 850 & 90 & 10.9 & 8 \\
\hline ASC-E2 \#7 and \#8 & 850 & 90 & 10.9 & 8 \\
\hline
\end{tabular}

\section{Nomenclature}

AC alternating current

ASC Advanced Stirling Convertor

ASRG Advanced Stirling Radioisotope Generator

ACU ASC Control Unit

DAQ data acquisition

DC direct current

E engineering-level Stirling convertor

E2 second generation of the engineering-level Stirling convertor

EU Engineering Unit

FLDT fast linear displacement transducer

FPC failsafe protection circuit

GPHS General Purpose Heat Source

GRC Glenn Research Center

LED light-emitting diode

PID proportional integral derivative

RMS root mean square

RTD resistance temperature detector

UPS uninterruptible power supply 


\section{Standard ASC Test Rack}

The standard ASC test rack is the basis for the development of all other test racks (Refs. 2 and 3). Each test rack discussed in this paper has the features of this test rack unless otherwise noted in its individual sections (Sections II, III, and IV).

\section{A. Data Acquisition System}

The data system utilizes National Instruments's LabVIEW-based data acquisition (DAQ) hardware and software to acquire data and monitor the test. It displays and records data on a computer, collects and saves data in various time frames, calculates parameters with received data, and provides safety to the convertors. The DAQ software, which was developed to operate in unattended mode, can control the support systems without user intervention.

Data collection allows for detailed analysis of convertor operation. To achieve this, LabVIEW collects and displays several parameters, including

- Heater voltage and current

- Heat-source temperature

- Hot-end temperature

- Cold-end temperature

- Cold-end coolant inlet and outlet temperatures

- Ambient temperature

- Cold-end coolant flow rates

- Pressure vessel temperature

- Alternator root mean square (RMS) voltage, RMS current, and power

- Piston amplitudes

- Operating frequency

- AC bus controller voltage and current

A complete data record of these parameters is stored every hour. In addition, the DAQ system maintains a buffer of data recorded over the last $24 \mathrm{hr}$ at a 2 -sec scan rate, records an average of the data over the last $5 \mathrm{~min}$ of every hour, and allows these data to be stored manually as needed for detailed analysis. From the stored data, numerous parameters are calculated, including

- Heater resistance and power

- System efficiency

- Power factor

- Average hot-end temperature

- Cold-end temperature

- Piston amplitude

- Net heat input

- Alternator motor constant

LabVIEW safety features are discussed in Section V, Subsection A.

\section{B. Control Systems}

The test rack provides two control systems: convertor and hot-end temperature control. Convertor control is performed by an $\mathrm{AC}$ bus that simulates the convertors being connected to an $\mathrm{AC}$ grid. The $\mathrm{AC}$ bus controller fixes the convertor frequency independent of changes in convertor dynamics. The operating 
frequency cannot deviate significantly from the intended convertor operating frequency. The power factor of each alternator indicates if the operating frequency deviates significantly from the natural frequency of each convertor. The AC bus controller controls piston amplitude by varying the AC voltage and, therefore, the load on the convertors. Increasing the AC voltage increases the piston amplitudes.

The controller dissipates power generated by the convertors in a load resistor, which is connected across the alternator output. The electrical load is sized for the maximum power output of the convertor. For convertors with low-voltage, high-current alternators, a transformer is used between the AC power supply output and the load resistor to enable the use of a more standard power supply. In addition the alternator is connected to tuning capacitors that compensate for the alternator inductance.

Hot-end temperature control is controlled with a heat-source controller. This controller regulates the power into the cartridge heaters that provide heat to the heat collectors of the convertors, thereby achieving constant-temperature control. Two independent heat-source controllers are capable of sourcing between 0 and $400 \mathrm{~W}$. The controller regulates electrical power to the heaters by means of two proportional integral derivative (PID) temperature controllers. These are programmed to limit the rate of change in power to $1{ }^{\circ} \mathrm{C} / \mathrm{sec}$. Programmable direct-current (DC) power supplies are driven by the PID controllers. Each hot-end temperature is controlled individually.

\section{Measurement}

The test rack receives signals from transducers, piston signal processors and accelerometer processors, and thermocouples. Alternator output is measured using voltage, current, and power transducers, which provide output signals ranging from 0 to $5 \mathrm{~V}$ to the DAQ system. Two sets of transducers are mounted in the test rack, where one panel measures heater voltage and current as well as $\mathrm{AC}$ bus controller voltage and current and the other panel measures alternator voltage, current, and power.

Obtaining an accurate position signal is desirable for observing trends in data. A Fast Linear Displacement Transducer (FLDT) integrated in the convertor senses piston position. The FLDT consists of a single coil and an Aluminum core. As the core moves in and out of the coil, the coil inductance changes with position. A processor calibrated with the FLDT produces the output signal. It processes and scales the signal into a usable form for the DAQ and safety interfaces in the test rack. In addition it allows the zero, polarity, and span of the signal to be adjusted.

An accelerometer measures any exported dynamics created by the convertors during operation. This information can be used to estimate net dynamic forces generated by the convertor pair and to monitor changes over time. Accelerometer signals connected to an amplifier provide a means to collect data from the accelerometer. These data are collected every $1,000 \mathrm{hr}$ of operation through a separate data system.

Thermocouples are used to measure the ambient temperature as well as temperatures of the heaterhead, cold-side adapter flange, pressure vessel, heat source, and coolant. These thermocouples are monitored by the DAQ and are used to trigger a shutdown of the convertors. Shutdown conditions are discussed in Section V, Subsection A.

Two steps are taken to verify measurements collected by the data system: calibration and testing. Measurement instruments - such as transducers, flow rate and pressure sensors, and the DAQ systemare calibrated yearly. Data are collected and analyzed on a regular basis to determine convertor performance, making the calibration of the equipment necessary to ensure accurate data. A test procedure is used to verify the measurements received by the DAQ system from instrumentation in the rack: transducer, piston, and pressure signals. This procedure is also executed when instrumentation that has been removed from the rack for calibration is reinstalled.

\section{Interface}

Several panels were designed to provide a means to interface the convertors and instrumentation in the test rack. These panels include a power, pressure, load, and flow meter signal conditioner interface. Interface panels used to implement safe operation of the convertors are discussed in Section V, Subsection B. 
The power panel serves as an interface for the AC power flow. Tuning capacitors, alternator output, convertor controller, and transducers interface to this panel. The pressure panel serves as an interface for pressure and position signals to the DAQ and protection devices. The load panel interfaces the electrical load, transformer, and AC bus controller. The flow meter signal-conditioner panel provides power to the flow meters. The flow meter signal is received and processed by LabVIEW. The flow meter signal conditioner is mounted and connected to allow for removal while the convertors are operating. The flow meter signal conditioner must be removed from the test rack for calibration.

\section{ASRG EU Test Rack}

The ASRG EU test rack can use either the AC bus controller or the ACU. Additional instrumentation, measurement, and calculations are needed to meet this requirement. The following sections describe either a change or addition to the standard ASC test rack.

\section{A. Data Acquisition System}

The DAQ for the ASRG EU test rack includes all parameters on a standard ASC rack with the addition of several others for operating with an ACU and for cooling system and temperature monitoring. The ACU provides data through analog and serial telemetry:

- DC bus voltage and current

- Analog piston position

- Analog alternator current

Cooling system monitoring for the ASRG EU is more detailed because it is air-cooled, whereas the standard ASC test setups provide cooling with a water/glycol mixture (Ref. 4).

Cooled air is circulated through the protective cover by fans. Figure 4 shows the ASRG EU cooling system. Additional parameters are measured for cooling system monitoring:

- ASRG EU housing temperatures

- Fan speed

- Upstream and downstream fan air temperatures

- Protective cover temperatures

- Argon pressure (Ref. 2)

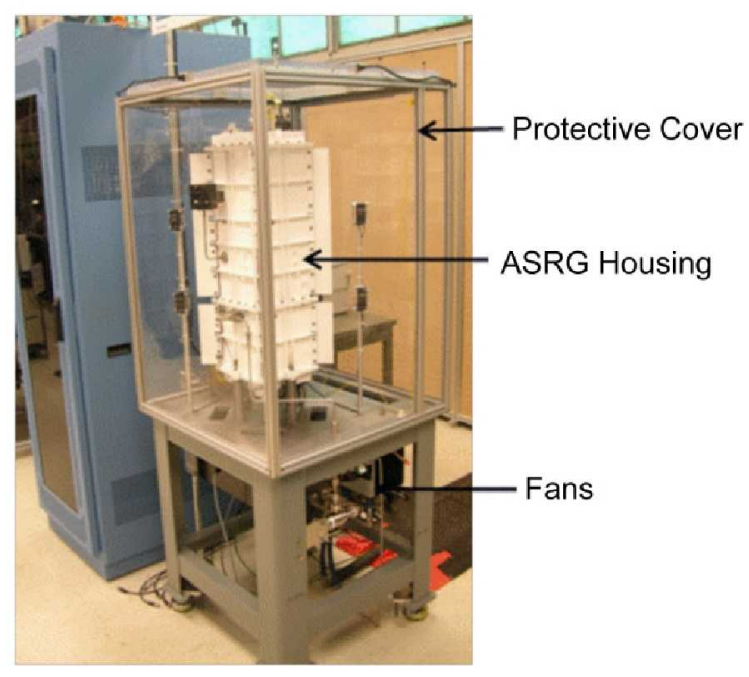

Figure 4.-ASRG-EU cooling system. 
The ASRG EU is instrumented with additional temperature-detection devices, including resistance temperature detectors (RTDs) and thermistors.

The DAQ also performs the following calculations:

- Controller efficiency

- Generator system efficiency

- Generator power

- Average housing temperature

- FLDT temperature

- Alternator current

- Piston amplitude

\section{B. Control Systems}

The test rack provides for two hot-end temperature-control systems and two convertor-control systems: constant heater temperature and fixed-heat input for temperature control, and AC bus and ACU for convertor control. Only one convertor control and one hot-end temperature control system are used in the test rack at one time. The ASRG EU test rack utilizes constant-temperature control for heat input when the convertor is operating with the $\mathrm{AC}$ bus controller, and it utilizes fixed-heat input control when the convertor is operating with the ACU. Fixed-heat input mimics operation with the General Purpose Heat Source (GPHS) module. The GPHS thermal output is independent of temperature. This value will slowly decrease from the time that it is assembled until the end of the mission, but at any one moment in time, it can be treated as a constant heat source. Constant-temperature operation is more straightforward to implement, but it may not be representative of the flight operation. Fixed-heat input is implemented with a microcontroller, with two independent heat-source controllers that are capable of sourcing between 0 and $300 \mathrm{~W}$ by regulating electrical power to the heaters.

Electronics in the ACU place requirements on the power path line resistance. The test rack was modified in two ways to accommodate this requirement. First, the power panel was moved from the back of the test rack to as close to the convertor as possible to reduce the length of wire in the power flow path. Second, external current sensors were used for current measurements. These modifications allow measurements to be taken close to the convertor rather than via a long cable from the convertor to the test rack.

AC bus control dissipates power in resistors. ASRG EU control relies on a DC electronic load to sink power. The ASRG EU output voltage is between 22 and $34 \mathrm{~V}_{\mathrm{dc}}$ and is determined by the end user. The ASRG EU will track to this voltage, providing power as a constant-power source, and will sense a bus overvoltage condition. The ASRG EU will provide constant power as long as the end user is in the required voltage range, but it will internally shunt power and disconnect itself from the bus if the voltage range is exceeded. Shunt resistors sized for maximum output power of the convertors are mounted on the load panel in the test rack for this purpose. The bus is connected to a capacitor bank for transient energy storage. This capacitor needs to be in the range of 10,000 to $100,000 \mu \mathrm{F}$.

\section{Measurement}

This ASRG-EU test rack allows for three measurements that were not available on the standard ASC test rack: thermistors and RTDs for temperature measurement and load cells for force measurement. Four thermistors measure pressure vessel and cold-end temperature. Six RTDs measure hot-end temperature. Four load cells measure the vertical, horizontal, and lateral loads at the interface between the test stand and the mechanical hardware. The signal is processed through an amplifier to allow data to be collected 
with a spectrum analyzer. The load cell readings are summed into single readings of force in the $x, y$, and $z$ directions. The DAQ system monitors the load cell signal in the $z$ direction; this signal is also monitored by safety protection devices, which are discussed in Section V.

\section{ASC-E2 Test Rack}

The ASC-E2 test racks are in the process of being designed and built. The first of four racks is scheduled to be complete in the fall of 2009. Because of the high value of the hardware to be tested, these test racks are being built to a higher quality standard than previous test racks. This effort includes updating documentation, purchasing instrumentation with greater accuracy, and following procedures for fabrication and inspection to ensure that each rack is built identically.

\section{A. Measurement}

Currently, two measurement techniques that are different from the standard ASC and ASRG-EU test racks will be implemented on the ASC-E2 test rack. The existing test racks at GRC measure alternator and heater voltage, current, and power with transducers. First, a power meter was selected that would improve the accuracy of and simplify the rack wiring and calibration process. Table 2 compares the fullscale accuracy of the transducer and power meter. Second, external current sensors will be used to measure current. This will minimize the line resistance in the power path of the convertors, which affects the operation of high-current, low-voltage convertors.

TABLE 2.-FULL-SCALE ACCURACY OF TRANSDUCERS AND POWER METERS

\begin{tabular}{|c|c|c|c|c|c|}
\hline $\begin{array}{c}\text { Voltage } \\
\text { transducer, } \\
\text { percent }\end{array}$ & $\begin{array}{c}\text { Current } \\
\text { transducer, } \\
\text { percent }\end{array}$ & $\begin{array}{c}\text { Power } \\
\text { transducer, } \\
\text { percent }\end{array}$ & $\begin{array}{c}\text { Power meter } \\
\text { voltage, } \\
\text { percent }\end{array}$ & $\begin{array}{c}\text { Power meter } \\
\text { current, } \\
\text { percent }\end{array}$ & $\begin{array}{c}\text { Power meter } \\
\text { power, } \\
\text { percent }\end{array}$ \\
\hline \pm 0.25 & \pm 0.25 to 0.5 & \pm 0.5 & 0.2 & 0.2 & 0.1 \\
\hline
\end{tabular}

\section{B. Documentation}

Developers have several goals for improving the documentation of the ASC-E2 racks. One goal is to improve the quality of the schematics. In the past, schematics were drawn in OrCAD and were not as detailed as should be used for test equipment for flight-like hardware. Work is underway to control the configuration by adding details such as parts lists, references, notes, wire sizes, lengths, and colors to the schematics. A second goal is to create schematics of circuits that were previously not documented. A third goal is to have all OrCAD schematics drawn in AutoCAD and filed in the Glenn Adept System. The quality of the test rack will be further improved through a design review with NASA senior engineers from outside of the organization. A fourth goal is to write a procedure to guide the assembly and checkout of the test racks to ensure that each rack is identical. This procedure will include steps needed to test each interface, control system, and measurement device; the order for installing each panel; and the wire length and routing for interfaces between the instrumentation and the convertors.

\section{Safety}

Safety systems on the test racks are implemented through the DAQ system and through hard-wired circuitry. The following subsections outline the unique safety systems on each test rack.

\section{A. LabVIEW DAQ Shutdown Sequence}

The user may specify upper and lower bounds for any parameter monitored by the DAQ system. The DAQ software will safely shut down operation of the test article when an out-of-bound condition is sensed. 
Parameters that trigger the shutdown of a standard ASC include low or high hot-end temperatures, low or high rejection temperatures, high pressure-vessel temperature, high piston amplitude, and loss of building power. If a shutdown is initiated, the DAQ commands the hot-end temperature to $10^{\circ} \mathrm{C}$ and circulator temperature to $25^{\circ} \mathrm{C}$, and it turns off the heater power supplies and AC bus controller. A shutdown is initiated for loss of building power after $5 \mathrm{~min}$ of operating on an uninterruptible power supply (UPS) system.

Parameters that trigger a shutdown of the ASRG-EU or ASC-E2 include low or high hot-end temperatures, high rejection temperatures, high pressure-vessel temperature, high piston amplitude, loss of building power, and high housing temperature. Both thermistors and thermocouples are used to detect shutdown conditions. If a shutdown is initiated, the DAQ commands the hot-end temperature to $10^{\circ} \mathrm{C}$ and the circulator temperature to $25^{\circ} \mathrm{C}$, and it turns off the heater power supplies. The convertors continue to be motored with the $\mathrm{AC}$ bus controller until the average hot-end temperature reaches $575^{\circ} \mathrm{C}$, with the nominal hot-end temperature being $625^{\circ} \mathrm{C}$. During the shutdown of a standard ASC, the piston motion is stopped, which prevents the transfer of heat. The change to continue to motor the convertor was implemented to allow the convertor to cool down more quickly.

Another safety feature in the software notifies the end user when a shutdown to prevent heat soak from the heat source occurs, logs the fault via the DAQ, and records the data. The end user is notified by a cell phone text message that indicates the fault code of the shutdown.

The DAQ shutdown functionality is tested via an unattended DAQ test rack checkout, which verifies that the sequence of each shutdown is correct. The shutdown scenarios are simulated with either a thermocouple calibrator or voltage reference.

\section{B. Hard-Wired Protection}

Three hard-wired protection devices installed in the operations rack function independently of the software-based protection (Refs. 2 and 3): temperature limit, protection circuit, and emergency push button.

Three panels and a DC power supply are used to initiate the temperature limit shutdown. The fault panel serves as an interlock for the heater power supplies. If a fault is registered by the temperature limit device, the DAQ, or an optional third source, the heater power supplies are disabled and a fault is indicated by a light-emitting diode (LED). A temperature panel houses the PID temperature controller and the temperature limit device. A thermocouple interface is provided between the DAQ and the temperature control panel. Feedback is provided to both the PID and the temperature limit device by two individual hot-end thermocouples. If the hot-end temperature of either convertor exceeds the user-defined limit, the limit controller removes the heater power from both convertors via a relay.

A failsafe protection circuit (FPC) was implemented to prevent piston overstroke. The FPC can monitor up to four input signals. Each input has an associated, user-adjustable setpoint. When any signal exceeds its setpoint, the convertor controller is disconnected, and an emergency load is applied across both alternators and a signal is sent to the DAQ. Piston-position sensor signals are the primary input on the standard ASC test rack, whereas the ASRG EU test rack has an additional input from the load cells. This input was added because it is independent of the piston signal from the ASRG EU controller. If the controller fails, the piston position signal would no longer be available to trigger a shutdown. The increased vibration from an overstroke of the piston would increase the load cell signal and trigger a shutdown.

A protection circuit interface panel provides a means for the user to be notified via LEDs when a piston amplitude limit is exceeded. The user can reset the protection circuit after the fault and can stall the convertors by a switch on this panel. The user also can disconnect the protection circuit and select between $\mathrm{AC}$ bus control and an external controller.

Several steps are required in the event of an emergency shutdown during convertor operation. These steps include removing power from the heaters, loading the convertor, and turning off the controller. An emergency shutdown button was created to simplify this process. This button initiates all of these steps with one action. This safety feature is being considered for integration in the ASC-E2 test rack; it is not available on either the ASC or ASRG EU test rack. 


\section{Conclusions}

The Stirling Research Laboratory can support various types of Advanced Stirling Convertor (ASC) operation in continuous, unattended mode. Three ASC test racks at NASA were presented. The standard ASC test rack provides alternating-current (AC) bus control and constant-temperature hot-end temperature control. The Advanced Stirling Radioisotope Generator Engineering Unit (ASRG EU) test rack supports both AC bus and ASC Control Unit (ACU) convertor control. In addition it supports both constant-temperature and fixed-heat input control. The ASC-E2 rack supports AC bus convertor control and constant-temperature hot-end temperature control. In addition, the quality of the documentation, procedures, and rack build are being improved. Table 3 summarizes the Stirling Research Laboratory test racks. The first ASC-E2 test rack is scheduled to be complete in the fall of 2009.

TABLE 3.-SUMMARY OF STIRLING RESEARCH LABORATORY TEST RACK DEVELOPMENT

\begin{tabular}{|c|c|c|}
\hline Standard ASC & ASRG-EU & ASC-E2 \\
\hline \multicolumn{3}{|c|}{ Measurement instrumentation } \\
\hline $\begin{array}{l}\text { Thermocouples } \\
\text { Transducers } \\
\text { Fast linear displacement transducer } \\
\text { (FLDT) processor } \\
\text { Accelerometers }\end{array}$ & $\begin{array}{l}\text { Thermistors } \\
\text { Resistance temperature devices (RTDs) } \\
\text { Thermocouples } \\
\text { Transducers } \\
\text { FLDT processor } \\
\text { Accelerometers } \\
\text { Load cells }\end{array}$ & $\begin{array}{l}\text { Thermocouples } \\
\text { Power meter } \\
\text { Accelerometers }\end{array}$ \\
\hline \multicolumn{3}{|l|}{ Convertor control } \\
\hline $\begin{array}{l}\text { Alternating-current (AC) } \\
\text { bus power supply }\end{array}$ & $\begin{array}{l}\text { AC bus power supply } \\
\text { ACU }\end{array}$ & AC bus power supply \\
\hline \multicolumn{3}{|l|}{ Temperature control } \\
\hline $\begin{array}{l}\text { Constant temperature } \\
\text { Water/glycol bath }\end{array}$ & $\begin{array}{l}\text { Fixed-heat input } \\
\text { Constant temperature } \\
\text { Air-cooled }\end{array}$ & $\begin{array}{l}\text { Constant temperature } \\
\text { Water/glycol bath }\end{array}$ \\
\hline \multicolumn{3}{|c|}{ Miscellaneous } \\
\hline & $\begin{array}{l}\text { Line resistance } \\
\text { Direct-current (DC) bus }\end{array}$ & $\begin{array}{l}\text { Line resistance } \\
\text { Documentation }\end{array}$ \\
\hline \multicolumn{3}{|c|}{ Safety } \\
\hline $\begin{array}{l}\text { Piston overstroke } \\
\text { LabVIEW } \\
\text { Hot-end temperature }\end{array}$ & $\begin{array}{l}\text { Load cells } \\
\text { Piston overstroke } \\
\text { LabVIEW } \\
\text { Hot-end temperature }\end{array}$ & $\begin{array}{l}\text { Emergency shutdown button } \\
\text { Piston overstroke } \\
\text { LabVIEW } \\
\text { Hot-end temperature }\end{array}$ \\
\hline
\end{tabular}

\section{References}

1. Cornell, P.A., Lewandowski, E.J., Oriti, S.M., and Wilson, S.D., "Stirling Convertor Extended Operation Testing and Data Analysis," Proceedings of the Seventh International Energy Conversion Engineering Conference (IECEC 2009), American Institute for Aeronautics and Astronautics, 2009.

2. Oriti, S.M., and Blaze, G.M., "Advanced Stirling Convertor Testing at NASA Glenn Research Center," Proceedings of the Fifth International Energy Conversion Engineering Conference (IECEC 2007), American Institute for Aeronautics and Astronautics, 2007.

3. Lewandowski, E.J., Schreiber, J.G., Wilson, S.D., Oriti, S.M., and Cornell, P.A., "Extended Operation Testing of Stirling Convertors in Support of Stirling Radioisotope Power System Development," Proceedings of the Sixth International Energy Conversion Engineering Conference (IECEC 2008), American Institute for Aeronautics and Astronautics, 2008.

4. Lewandowski, E.J., Schreiber, J.G., Oriti, S.O., Meer, D.W., and Dugala, G.M., "Design of a Facility to Test the Advanced Stirling Radioisotope Generator Engineering Unit," Proceedings of the Seventh International Energy Conversion Engineering Conference (IECEC 2009), American Institute for Aeronautics and Astronautics, 2009. 


\begin{tabular}{|c|c|c|}
\hline \multicolumn{2}{|c|}{ REPORT DOCUMENTATION PAGE } & $\begin{array}{c}\text { Form Approved } \\
\text { OMB No. 0704-0188 }\end{array}$ \\
\hline \multicolumn{3}{|c|}{ 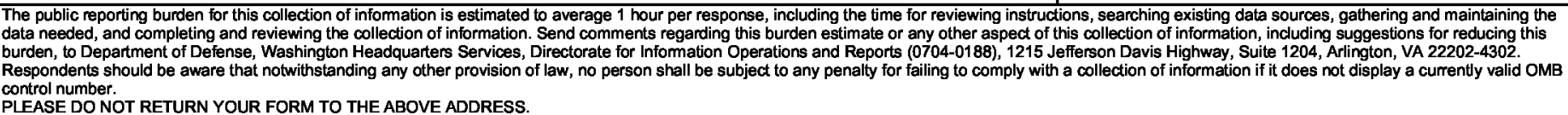 } \\
\hline $\begin{array}{l}\text { 1. REPORT DATE (DD-MM-YYYY) } \\
01-03-2010\end{array}$ & $\begin{array}{l}\text { 2. REPORT TYPE } \\
\text { Technical Memorandum }\end{array}$ & 3. DATES COVERED (From - To) \\
\hline \multirow{3}{*}{\multicolumn{2}{|c|}{$\begin{array}{l}\text { 4. TITLE AND SUBTITLE } \\
\text { Test Rack Development for Extended Operation of Advanced Stirling Convertors at NASA } \\
\text { Glenn Research Center }\end{array}$}} & 5a. CONTRACT NUMBER \\
\hline & & 5b. GRANT NUMBER \\
\hline & & 5c. PROGRAM ELEMENT NUMBER \\
\hline \multirow{3}{*}{\multicolumn{2}{|c|}{$\begin{array}{l}\text { 6. AUTHOR(S) } \\
\text { Dugala, Gina, } \mathrm{M} \text {. }\end{array}$}} & 5d. PROJECT NUMBER \\
\hline & & 5e. TASK NUMBER \\
\hline & & $\begin{array}{l}\text { 5f. WORK UNIT NUMBER } \\
\text { WBS } 138494.04 .01 .01\end{array}$ \\
\hline \multicolumn{2}{|c|}{$\begin{array}{l}\text { 7. PERFORMING ORGANIZATION NAME(S) AND ADDRESS(ES) } \\
\text { National Aeronautics and Space Administration } \\
\text { John H. Glenn Research Center at Lewis Field } \\
\text { Cleveland, Ohio 44135-3191 }\end{array}$} & $\begin{array}{l}\text { 8. PERFORMING ORGANIZATION } \\
\text { REPORT NUMBER } \\
\text { E-17219 }\end{array}$ \\
\hline \multirow{2}{*}{\multicolumn{2}{|c|}{$\begin{array}{l}\text { 9. SPONSORING/MONITORING AGENCY NAME(S) AND ADDRESS(ES) } \\
\text { National Aeronautics and Space Administration } \\
\text { Washington, DC 20546-0001 }\end{array}$}} & $\begin{array}{l}\text { 10. SPONSORING/MONITOR'S } \\
\text { ACRONYM(S) } \\
\text { NASA }\end{array}$ \\
\hline & & $\begin{array}{l}\text { 11. SPONSORING/MONITORING } \\
\text { REPORT NUMBER } \\
\text { NASA/TM-2010-216232 }\end{array}$ \\
\hline \multicolumn{3}{|c|}{$\begin{array}{l}\text { 12. DISTRIBUTION/AVAILABILITY STATEMENT } \\
\text { Unclassified-Unlimited } \\
\text { Subject Category: } 20 \\
\text { Available electronically at http://gltrs.grc.nasa.gov } \\
\text { This publication is available from the NASA Center for AeroSpace Information, 443-757-5802 }\end{array}$} \\
\hline
\end{tabular}

\section{SUPPLEMENTARY NOTES}

\section{ABSTRACT}

The U.S. Department of Energy, Lockheed Martin Space Systems Company, Sunpower Inc., and NASA Glenn Research Center (GRC) have been developing an Advanced Stirling Radioisotope Generator (ASRG) for use as a power system on space science missions. This generator will make use of free-piston Stirling convertors to achieve higher conversion efficiency than with currently available alternatives. One part of NASA GRC's support of ASRG development includes extended operation testing of Advanced Stirling Convertors (ASCs) developed by Sunpower Inc. and GRC. The ASC consists of a free-piston Stirling engine integrated with a linear alternator. NASA GRC has been building test facilities to support extended operation of the ASCs for several years. Operation of the convertors in the test facility provides convertor performance data over an extended period of time. One part of the test facility is the test rack, which provides a means for data collection, convertor control, and safe operation. Over the years, the test rack requirements have changed. The initial ASC test rack utilized an alternating-current (AC) bus for convertor control; the ASRG Engineering Unit (EU) test rack can operate with AC bus control or with an ASC Control Unit (ACU). A new test rack is being developed to support extended operation of the ASC-E2s with higher standards of documentation, component selection, and assembly practices. This paper discusses the differences among the ASC, ASRG EU, and ASC-E2 test racks.

\section{SUBJECT TERMS}

Advanced Stirling radioisotope generator; Power systems; Stirling convertors

\begin{tabular}{|l|l|l|l|l|l|}
\hline \multicolumn{2}{|l|}{ 16. SECURITY CLASSIFICATION OF: } & $\begin{array}{l}\text { 17. LIMITATION OF } \\
\text { ABSTRACT }\end{array}$ & $\begin{array}{l}\text { 18. NUMBER } \\
\text { OF } \\
\text { PAGES }\end{array}$ & $\begin{array}{l}\text { 19a. NAME OF RESPONSIBLE PERSON } \\
\text { STI Help Desk (email:help@sti.nasa.gov) }\end{array}$ \\
\cline { 1 - 2 } $\begin{array}{l}\text { a. REPORT } \\
\text { U }\end{array}$ & $\begin{array}{l}\text { b. ABSTRACT } \\
\text { U }\end{array}$ & $\begin{array}{l}\text { c. THIS } \\
\text { PAGE } \\
\text { U }\end{array}$ & UU & 16 & $\begin{array}{l}\text { 19b. TELEPHONE NUMBER (include area code) } \\
\text { 443-757-5802 }\end{array}$ \\
\hline
\end{tabular}



